\title{
Governance Indicators for Effective Management of Mangrove Resources
}

\author{
A. M. Dyg Affizzah (Corresponding author) \\ Department of Economics, Faculty of Economics and Business \\ Universiti Malaysia Sarawak, 94300 Kota Samarahan, Sarawk, Malaysia \\ Email: amdaffizah@unimas.mu
}

Salbiah E.

Department of Economics, Faculty of Economics and Business

Universiti Malaysia Sarawak, 94300 Kota Samarahan, Sarawk, Malaysia

\author{
A. B. Nor Afiza \\ Department of Economics, Faculty of Economics and Business \\ Universiti Malaysia Sarawak, 94300 Kota Samarahan, Sarawk, Malaysia
}

E. M. Shuib

Department of Economics, Faculty of Economics and Management

Universiti Putra Malaysia, 93400, Serdang, Selangor, Malaysia

Received: October 11, 2016 Accepted: October 30, 2016 Published: November 28, 2016

doi:10.5296/jpag.v6i4.10334 URL: http://dx.doi.org/10.5296/jpag.v6i4.10334

\begin{abstract}
Mangroves and marshes provide mutual benefits in terms of providing aquatic eco-systems. Swamp forests contribute a variety of services to carry out activities that depend on water resources such as agricultural production, fishing and tourism. The destruction of mangrove forests is alarming despite the benefits we are receiving. A major reason for excessive depletion and conversion of wetland resources is often the failure to account adequately for their non market environmental values in developmental decision. The management role of
\end{abstract}


the relevant agencies will only be effective pending supports by other stakeholders who may benefit directly or indirectly from the mangrove forest. Thus the approach should not only focus on the technical nor economic and socio political issues only but to reinforce the relationships of the players or actors who have interest in the domain of mangrove forest. This study aims to identify the process of governance and its effectiveness in managing the ecosystem and also assessing the role of mangrove forests towards local communities in Kuching Wetlands. Items are analyzed using factor analysis and the factor extraction leads to multiple regression method. The study distinguish that among the important factors in influencing the public perception of local governance mangrove forests in Kuching Wetlands, are community awareness, handling problems and conflict in the existing rules while other factors were not significant. However, most of the wetland local community does not contribute to ecotourism industry, even though they are aware of the importance if sustaining it. Thus the government can take opportunity to raise the awareness via the potential income that can be generated from eco tourism activities and realizing its importance of sustaining the natural resources.

Keywords: Ecotourism, Governance effectiveness, Perception, Socio economic

\section{Introduction}

Wetlands are an important component of the environment and their precious environment source. Nowadays, wetlands are influenced by current trends in urbanization due to the high rate of population growth leads to high demand for land for development, including tourism, fisheries, transportation, mining, and communication. These multiple uses, combined with rapid economic and industrial growth in recent decades, have attracted an increasing number of people to live in coastal areas (IUCN, 2006). Population increases with its related consequences have resulted in depleted and degraded wetlands and marine resources. Mangrove forests and wetlands are essential in providing water-related ecosystem services, such as clean water for drinking, water for agriculture, cooling water for the energy sector and regulating water quantity (e.g. flood regulation). In conjunction with their role in erosion control and sediment transport, wetlands also contribute to land formation and therefore resilience to storms. Moreover, they provide a wide range of services that are dependent on water, such as agricultural production, fisheries and tourism.

Various human activities in changing natural environment cause system degradation wetlands (Gillespie, 2007). There are both direct and indirect effects of development on wetlands such as infrastructure development, which leads to changes hydrological cycle, among others. The continued loss of mangroves and wetlands illustrates the need for improved policy making and business decision making that accounts for their true value. Without wetlands, the water cycle, carbon cycle and nutrient cycle would be significantly altered, mostly detrimentally. The need for the wise use and conservation stems from the recognition of high-value goods and services these ecosystems provide to society (Ramsar Convention on Wetlands \& World Tourism Organization (UNWTO), 2012). 


\section{Problem Statement}

A major reason for excessive depletion and conversion of wetland resources is often the failure to account adequately for their non-market environmental values in development decisions (Barbier et al., 1997). By providing a means for measuring and comparing the various benefits of wetlands, economic valuation can be a powerful tool to aid and improve wise use and management of wetland resources (Barbier et al., 1997).. Meanwhile in the paper of Shuib, Lee and Edman (2012), the large tract of the mangrove forest area in the district has undergone exploitation for aquaculture projects cultivation and quarrying activities. Besides, in several locations of mangrove plant area has been turned into garbage dumps (Sarawak Forestry Department, 2010). All these actions have affected the natural fisheries, wildlife and residents daily live.

Concerned with the rapid depletion of the mangrove and wetland ecosystems, relevant government agencies are normally created and given the responsibilities to ensure that the establishment of the protected areas will achieve the objectives of protecting the ecosystem which are of national and perhaps of international interests. The management role of the relevant agencies will only be effective pending supports by other stakeholders who may benefit directly or indirectly from the mangrove forests. The roles of other players and actors in enhancing the management of the mangrove forests and wetlands are undertaken via governance of the ecosystems. The establishment of a protected area is in fact an establishment of the tools for governance (IUCN, 2006).

In light of the issues raised above, it is therefore important to quantify the value of wetland resources for the communities living around the wetland as well as the nation, to realize the valuable benefits the wetlands provides in order to improve wise use and management of its resource. Kooiman and Chuenpagdee ( 2005, ) define governance as 'The whole of interactions taken to solve societal problems and to create societal opportunities; including the formulation and application of principles guiding those interactions and care for institutions that enable and control them'. The approach to governance of the protected ecosystems is not to focus on the neither technical nor economic and socio political issues only but to reinforce the relationships of the players or actors who have interests in the domain of mangrove forests and wetlands. The multiple use character of the mangrove forests and wetlands require that the governance of these areas focusses on upholding application of the norms within the mangrove forest areas and wetlands (Noël and Weigel, 2007).

The local communities living in the periphery of mangrove forests and wetlands are dependent directly or indirectly on the natural resources within the wetlands where the conservation of ecosystem is undertaken. It is pertinent in order to obtain supports for the governance of the mangrove forests and wetlands, the local communities must believe or perceive that there is a synergy between conservation and usage of the resources to support the livelihood of the communities (Pomeroy, Lani, John, Gonzalo, 2005). The support can only be achieved if there is recognition that the objectives of governance of mangrove forests and wetlands is to achieve the multiple goals of conservation of the ecosystem without neglecting local culture and to establish that the first beneficiaries of the project must 
be the local communities. Bovaird, (2005) suggests that synergy between conservation and socio-economic development is a fundamental issue in governance of mangrove forest and wetlands since the gazzettement of the protected area will limit, forbid or otherwise control the patterns and human activity through the structure of rights and rules.

However there is usually major confusion in the notion of governance of the natural resources among the stakeholders because the interrelationships of the socio-economic-political features that form the socio-economic organizations and institutions that shape the governance of the mangrove forests and wetlands are ambiguous and complex. The approach to governance of the protected ecosystems is not to focus on the technical or economic and socio political issues only but to reinforce the relationships of the players or actors who have interests in the domain of mangrove forests and wetlands. Due to land use and climate change as results varied human activities, there is a strong need to manage wetlands in a holistic approach to strengthen the work done by other bodies in maintains the natural environment and sustainability. Various policies have been formulated however implementation of the policies sometimes do not sufficiently take into account these interconnections and interdependencies.

Therefore the study is to establish indicators and measurement of governance for the mangrove forests and wetlands in Sarawak, particularly in Semariang, Kuching Wetlands, a RAMSAR site. This research would provide for the level of awareness of the local communities, as well as the roles of governance in affecting the management of the mangrove protected areas and wetlands. It shall lead to appropriate recommendation on better governance for effective management of mangrove forest and wetland resources. Questionnaires and focus groups were conducted in five mukim in Sarawak and analyses using factor analyses were utilized in order to extract the index. Ability to construct an index for good mangrove governance will benefits local government, forestry and fisheries administrators, researchers, and local communities for the dynamics of ecosystems, markets, the social, cultural and political environment, and the multiple temporal and spatial scales of activities.

Mangrove forests in Malaysia are more diverse than other areas such as tropical Australia, tropical Africa and Americas. In Malaysia, the overall loss amounts to about 16\%, some states have lost as much as $30 \%$ to $70 \%$ of their original areas (Chan et al., 1993). One of the popular mangrove forests in Malaysia is Matang mangrove forest in Perak. Matang mangrove forest is the largest mangrove forest reserve in Malaysia.

In Malaysia thousands of hectares of mangroves have been cleared to make way for buildings, infrastructure, aquaculture ponds and agricultural fields. In particular large tracts of mangroves and coral reefs have been cleared for aquaculture and agriculture. And a lot of these aquaculture ponds have been abandoned quickly as a result of shrimp diseases and decreasing productivity. This leaves the affected coastal areas unprotected and unproductive. Urban development, pollution, over-harvesting of wood in the coastal forests and destructive fishing have further contributed to the destruction and degradation of mangrove forests. Malaysia's mangroves have declined over $45 \%$ from an estimated 1.1 million hectares to the 
current estimate of 564,970 hectares (Wetlands International, n.d.). Though the government has established a national committee to oversee research and replanting efforts, remaining mangroves continue to be threatened through illegal encroachment and drainage.

An estimated $29 \%$ of our country's $4,000 \mathrm{~km}$ coastline has been classified as facing serious erosion. For example, Tanjung Piai, the southernmost point of Asia's mainland and one of Malaysia signed the Ramsar Convention on Protection of Wetlands in 1994 with Tasek Bera being nominated as the country's first Ramsar site. The Ramsar Convention is an intergovernmental treaty which provides the framework for national action and international cooperation for the conservation and sustainable use of wetlands and their resourcesis national park in Malaysia.Malaysia's Ramsar sites, is suffering from severe erosion of up to 9 meters per year (Wetlands International, n.d.).

Table 1: Wetlands of international importance in Malaysia

\begin{tabular}{|c|c|c|c|c|}
\hline \multicolumn{2}{|c|}{ NoName } & \multirow{2}{*}{$\begin{array}{l}\text { District } \\
\text { Bera }\end{array}$} & \multicolumn{2}{|c|}{$\begin{array}{l}\text { Area Ramsar Designation } \\
\left(\mathrm{km}^{2}\right) \text { Date }\end{array}$} \\
\hline 1 & Bera Lake & & 311 & November 1994 \\
\hline 2 & Pulai River & Pulai River & 91 & January 2003 \\
\hline 3 & Kukup Island & Pontian & 6 & January 2003 \\
\hline 4 & Tanjung Piai & Pontian & 5 & January 2003 \\
\hline 5 & Kuching Wetlands National Park & Kuching & 170 & November 2005 \\
\hline 6 & Lower Kinabatangan Segama We & dKinabatanga & n788 & October 2008 \\
\hline
\end{tabular}

Source: Wetlands International (n.d.)

In Sarawak, the mangrove area north of Kuching name as Kuching Wetlands has been designated as a Ramsar site in November 2005. Kuching Wetlands National Park (KWNP) covers an area of 6610 hectares, is the only approved Ramsar Site in Sarawak, as stated in the Ramsar Convention. KWNP gazetted as a national park in July 2002 as a totally protected area. It is the remains of former Sarawak Mangrove Forest Reserve, which previously closed about 17, 000 hectares. The Tourism Ministry is stepping up efforts to promote KWNP as important destination for local and international tourists (Chia, 2012). Chia (2012) reported that KWNP recognition as Ramsar wetlands made it the first listed in Sarawak and wetlands listed fifth in Malaysia. Eighty per cent of it comprises mangroves, peat swamps and 'kerangas' (heath) forest. In definition, any Ramsar site is a conservation area protected under the Ramsar Convention, which formally stands for 'Convention on Wetlands of International 
Importance Especially as Waterfowl Habitat'.

The mangrove forest plays a major role in protecting the river banks against wave action, provides breeding grounds for fish and serves as their food source as well as a source of food and refuge for wildlife. The endangered proboscis monkeys in KWNP consume almost exclusively 'perepat' 4 . Besides being the breeding sanctuary and habitats for animals, Kuching Wetland National Park is also home to about 8,000 residents of seven villages which are Kampung Telaga Air, Kampung Sibu Laut, Kampung Sungai Aur, Kampung Temenggong, Kampung Pulau Salak, Kampung Semariang Batu and Kampung Mersan. Most of the villagers in these seven villages depend on KWNP for their daily needs (Chia, 2012).

Ever since tourism activities are started booming, the residents had a huge opportunity to supply the boat services to bring visitors from Kampung Telaga Air or Santubong Jetty to look around KWNP. KWNP has a long attracted nature and excellent wildlife viewing opportunities. Besides that, the mangrove forest in Kuching district provides a wide array of raw materials as a major source of income generation and subsistence for the local communities. The principle activities of local people are fishing, logging, farming, and charcoal production in the mangrove forest. However, the forest has undergone the exploitation for an aquaculture project, cultivation and quarrying activities. There is also the illegal hunting of animals. If the mangrove forest continues to undergo exploitation, this may lead to environmental degradation and effects on natural fisheries and wildlife.

In this study, it focuses on the Samariang mangrove wetland that has shown high degree of destruction of its forest. The original area of 17153 ha has been reduced by to the present area of 11651 ha. Economic activities such as aquaculture project, cultivation and quarrying activities are the main causes of reduction of mangrove forest area. There is 1449 ha of mangrove forest that is being clear-felled for an aquaculture project and this causes a subsequent loss of $11 \%$ of the Forest Reserve. All these actions have affected the natural fisheries and wildlife. Furthermore, these actions also cause environmental degradation. Goals in urban wetland restoration often are unrealistic because they do not consider ongoing and large scale human disturbances (Grayson, Chapman \& Underwood, 1999). The other study by Hails (1996) saying that many parts of the world have experienced loss or degradation of wetlands on a huge scale because of agricultural use, urbanization, excessive exploitation by local populations and ill planned developmental activities. All these actions have affected the natural fisheries and wildlife. Due to the urbanization that occurred in the Samariang occur from year to year, the Samariang residents not relying fully on the use of mangroves in everyday life and causes of lack of awareness to consume on the mangroves.

\section{Theoretical Framework}

Figure 1 shows the extent to which the environment management system is multidisciplinary, together with insights into different theoretical approaches and the mechanisms therein. It can be observed that ecological, capital and labor, state and power, and society and culture theories have been separately used to describe and explain the biophysical or ecological process, economic process, political processes, and socio-cultural issues respectively. These combinations of different theories, each with a different focus, together provide a very 
complex and dynamic approach to environmental management.

Figure 1: Elements in a Resource Management System

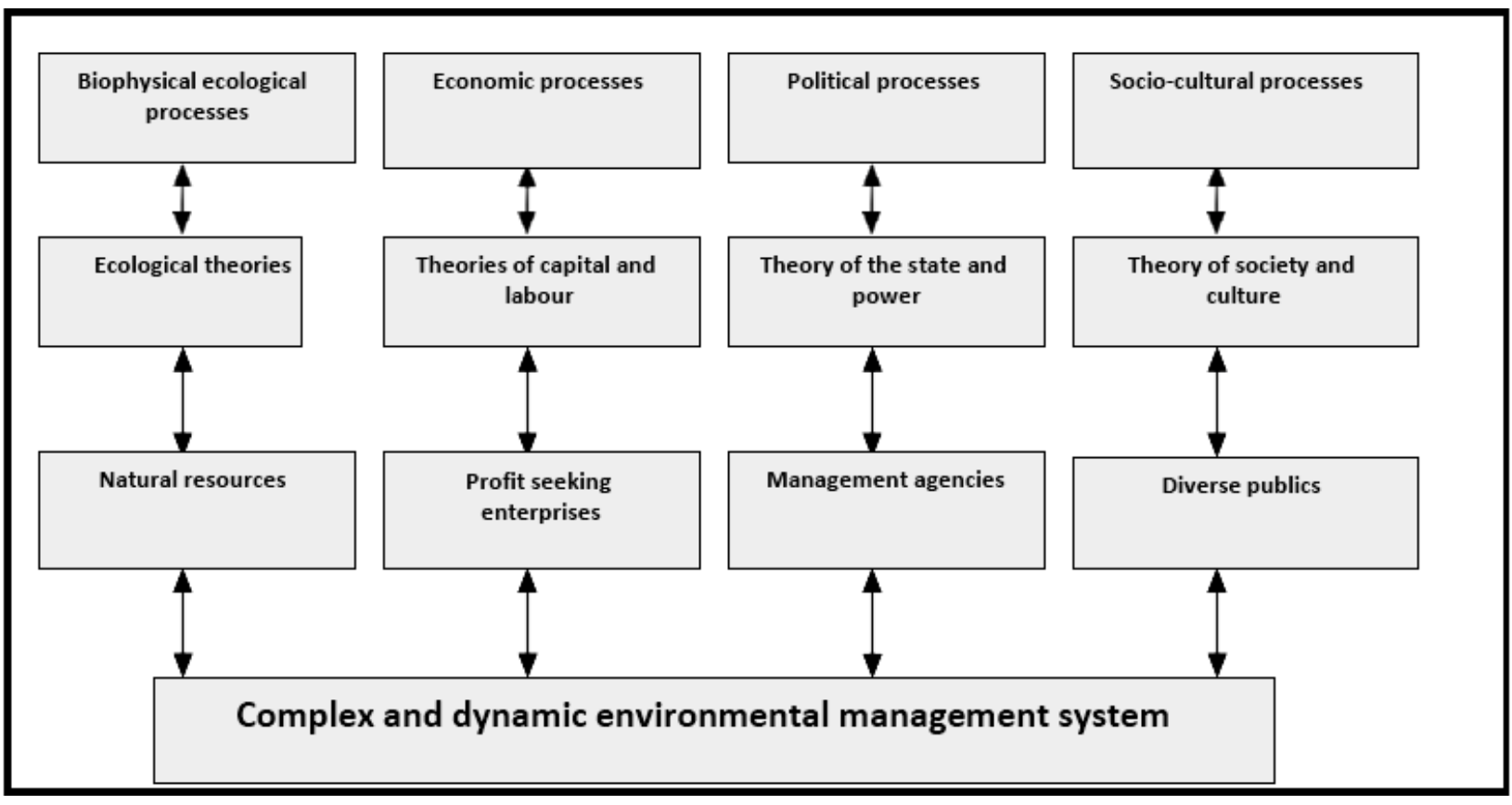

Source: Adopted and modified from Howitt, (2001)

Wetland management can be conceptualized by considering issues within the framework of social, political and institutional. The discussion around the key elements of the argument is based on the principle that effective management of wetlands is not exacerbated by, among others, the lack of public knowledge management and the capacity to act, and by weak institutions. Management failures eventually led to the spread of high poverty and stagnant development. Theory institutional frameworks focus on the institutional structure of wetland management, empowerment theory is concerned with capacitating communities to wetland management, and addresses the hypothesis ecosystem function of wetland ecosystems.

\section{Methodology}

\subsection{Data Collection}

In this research, all the data and information are collected by using primary and secondary sources. There are 160 questionnaires collected during this study. The participants of this study were the local communities of Kuching Wetlands including Kampung Samariang Batu, Kampung Sungai Midin and Kampung Samariang Pinggir. Whom are mostly Malays. Majority of the residents involved in fisheries, followed by business activity and public or private employees. The questionnaire was divided into four sections such as; were 4 Section 1: Respondent's profile, Section 2: Socioeconomic background, Section 3: Mangrove forest resources, and Section 4: Wetland management. 


\section{Mll Macrothink}

Journal of Public Administration and Governance

ISSN 2161-7104

2016, Vol. 6, No. 4

Section 1 involved a set of open-ended questions which asked for the personal detail of the respondent, such as age, sex, size of household, academic level and membership in any organization or association. Section 2 was designed to ask for the respondents' income that is related to mangrove resources such as fisherman, tourism and business. Meanwhile Section 3 adapted Likert-scale questions with five potential choices, which indicate for 'strongly disagree', 'disagree', 'neutral', 'agree' and 'strongly agree' respectively. The questions or statements stated in this section covers for the knowledge on mangrove forest resources, ex. whether the villagers are well known about situation of mangrove forest or not. The last section, Section 4 focuses on the management of wetland in Kuching Wetlands, Samariang. This section is to determine whether the villagers are aware about the management of wetland and are the wetland management is effective enough to conserve the wetland.

The data will be divided into qualitative and quantitative. The qualitative data and quantitative data will be organized into a frequency distribution. The frequency tables (frequency), percentage forms were used to mainly analyze the demographic characteristics of the respondents.

\subsection{Factor Analysis}

In this study, an exploratory factor analysis (EFA) was utilized. According to McDonald (1985), a factor analysis is a "generic term for a somewhat vaguely delimited set of techniques for data processing, mainly applicable to the social and biological sciences". These techniques have been generated for the interpretation of correlative relationships amongst a number of measurements made on a number of measurable entities and therefore it was decided to explore the data using this process. Factor analysis seeks to discover common factors. It is the technique for extracting factors that try to take out as much common variance as possible in the first factor and the following factors are, intended to account for the maximum amount of the remaining common variance until, hopefully, no common variance remains (Suhr, n.d.).

\subsection{Reliability Test}

Reliability is a measure of consistency. It is a measure of whether the questions constructed in a questionnaire can be accepted or not. Cronbach's Alpha is the most common measure of scale reliability, where the value of 0.7 to 0.8 is considered as acceptable value (Field, 2006). Although the generally accepted value is 0.8 is appropriate for cognitive tests, for ability tests a cut-off point of 0.7 is more suitable (Kline, 1999). In this research, Cronbach Consistency Reliability test were adopted. A common acceptable rule of thumb for describing the internal consistency using Cronbach's Alpha is as given in Table 2 below (Gandhi, 2012): 


\section{Macrothink

Table 2: Interpretation of Cronbach's Alpha

\begin{tabular}{ll}
\hline Cronbach's Alpha & Internal Consistency \\
\hline$<0.5$ & Unacceptable \\
$0.5-0.6$ & Poor \\
$0.6-0.7$ & Questionable \\
$0.7-0.8$ & Acceptable \\
$0.8-0.9$ & Good \\
$0.9-1.0$ & Excellent \\
\hline
\end{tabular}

Source: Gandhi (2012)

\subsection{Indexing}

Indexing method is applied to measure the variable of perception of the respondents. For example, in the questionnaire Section 4 which is consists of 47 Likert-scale questions to test for the perceptions on the wetland management. The following formula is used to measure the variable of the respondents:

$\operatorname{Index}_{i}=\frac{\sum X x_{i}}{n}$

(Eq. 1)

Where;

$X=$ Likert scale $(1,2,3,4,5)$

$i=$ Question's number

$n=$ No. of questions

\subsection{Multiple Regressions}

Multiple regressions allow the evaluation of the association between a set of independent variables and a dependent variable. Multiple regressions can also evaluate the relative importance of the each independent variable to the change in the dependent variable scores. 


\section{Macrothink}

To examine the factors that influences the attitudes of local people towards the conservation of wetlands by using the attitude of local people data as a dependent variable. Multiple regressions are an extension of simple linear regression (Laerd Statistics, n.d.) The general purpose of multiple regressions is to learn more about the relationship between several independent or predictor variables and a dependent or criterion variable (StatSoft, n.d.). Every value of the independent variable is associated with a value of the dependent variable. The regression model for this study can be written as the followings:

$$
\begin{aligned}
& P R=\propto+\beta_{1} \text { Index }_{1}+\beta_{2} \text { Index }_{2}+\beta_{3} \text { Index }_{3}+\beta_{4} \text { Index }_{4}+\beta_{5} \text { Index }_{5}+ \\
& \beta_{6} \text { Index }_{6}+\beta_{7} \text { Index }_{7}+\beta_{8} \text { Index }_{8}+\beta_{9} \text { Index }_{9}+\beta_{10} \text { Index }_{10}+\beta_{11} \text { Index }_{11}+ \\
& \beta_{12} \text { Index }_{12}+\varepsilon
\end{aligned}
$$

(Eq. 2)

Where,

PR = Perceptions of the respondents on wetlands management

Index $_{1}=$ Conflict of Community on Existing Regulations

Index $_{2}=$ Effectiveness of Existing Regulations on Wetlands Management

Index $_{3}=$ Community Engagement on Wetlands Management

Index $_{4}=$ Wetlands Existence

Index $_{5} \quad=$ Relationship with Authorities

Index $_{6}=$ Community Awareness

Index $_{7}=$ Government Involvement

Index $_{8}=$ Conflict Resolution

Index $_{9}=$ Conflict on Resources

Index $_{10}=$ Community Involvement on Regulations 
Index $_{11}=$ Regulation Affect Resources

Index $_{12}=$ Wetlands Management Budget

$\alpha$ and $\beta \mathrm{i}=$ Parameters to be estimated

\section{Results and Discussion}

An Explanatory Factor Analysis (EFA) was conducted by utilizing SPSS version 20 for a sample of 158 respondents. It is a technique for identifying groups or clusters of variables. EFA can be used to (i) understand the structure of a set of variables; (ii) to construct a questionnaire to measure core variables and (iii) to reduce a data set to a more manageable size while retaining as much of the original information as possible (Field, 2006). All 47 items of Kuching Wetlands' perception of local community towards the implementation of wetland management were subjected to principal component analysis and reliability analyses. The EFA utilized principal component extraction with Varimax rotation to assess the dimensionality of the data.

In the initial EFA, the extraction is done without specifying the number of factors to be retained. The preliminary purification examination resulted in the deletion of twelve items. Table X displays for the result for both Kaiser-Mayer-Olkin (KMO) measure of sampling adequacy and the Bartlett test of sphericity for the sample. The KMO expectation scale of sampling adequacy measure was 0.833 and well above the recommended threshold of 0.6 (Keiser, 1974), indicating that present data were suitable for principal component analysis (Meyers et al., 2006, Hair et al., 2007). The Bartlett's test of sphericity was 9461.87 and significant ( $p=0.000$ ) which signified that there was sufficient inter-item correlation with the data for conducting factor analysis (Sharma, 1996).

Table 2: KMO and Bartlett's Test

Kaiser-Meyer-Olkin Measure of Sampling Adequacy. 0.833

Approx. Chi-Square $\quad 9461.87$

Bartlett's Test of Sphericity df $\quad 1081$

Sig. $\quad 0.000$

From the data collected, twelve factors were extracted explaining $68.13 \%$ of the variance. This was decided based on eigenvalues greater than 1 and cumulative variance as well as from the inspection of the scree plot. The rule of Kaiser's eigenvalue greater than 1 criterion 
(Fabrigar et al., 1999) states that all factors greater than 1 should be retained for interpretation. The second criteria that were used to determine the number of factors is by setting the level of cumulative variance where a minimum of $60 \%$ cumulative variance is commonly accepted (Hair et al., 2006). By combining this result, coupled with the eigenvalue analysis and scree plot examination supports for a twelve- factor solution. Factors were obliquely rotated using Varimax rotation and the interpretation of the twelve factors means that there is a twelve-dimensional theory of respondents' perception of local community towards the implementation of wetland management at the Kuching Wetlands. A summary for the respondents' latent factor constructs is described in Table 3.

Table 3: Latent Factor Constructs

\begin{tabular}{lcl}
\hline Factor & Statements & Motivations \\
\hline Factor 1 & 8 items & Conflict of Community on Existing Regulations \\
Factor 2 & 9 items & Effectiveness of Existing Regulations on Wetlands Management \\
Factor 3 & 2 items & Community Engagement on Wetlands Management \\
Factor 4 & 2 items & Wetlands Existence \\
Factor 5 & 3 items & Relationship with Authorities \\
Factor 6 & 2 items & Community Awareness \\
Factor 7 & 2 items & Government Involvement \\
Factor 8 & 2 items & Conflict Resolution \\
Factor 9 & 1 item & Conflict on Resources \\
Factor 10 & 1 item & Community Involvement on Regulations \\
Factor 11 & 2 items & Regulation Affect Resources \\
Factor 12 & 1 item & Wetlands Management Budget \\
\hline
\end{tabular}

The next step is to measure the reliability of the questionnaire. A value of greater than 0.5 signifies that the questions in the questionnaire are relatively easy to be understood by the respondents. In this research, the overall Cronbach's Alpha is found at 0.893, which is an excellent score, indicating that the reliability of the scale used in this research is acceptable. Thus, it can be concluded that the questionnaire that have been distributed can be easily understood by respondents.

In addition, the reliability of all the subscales individually will be measured. To summarize, the reliability for all the factors is between 0.5 and 0.8 which indicates that the results from the analysis is quite reliable. There are four factors that been rejected through reliability test and only eight factors retained to the next step (to convert into Index form). In the next section, an Indexing method will be performed in order to proceed to the following step which is the regression. Prior to the regression of the data in the index forms, the assumptions of normal distribution, linearity relationship and homo-scedasticity have been carried out and the data has "passed" all the assumptions to enable regression.

\subsection{Regression Model}

Below is the regression model computed by the SPSS software. 


\begin{tabular}{|c|c|c|c|c|c|}
\hline $\mathrm{PR}=$ & $2.174+$ & $0.118 \operatorname{Index}_{1}$ & $0.004^{\text {Index }_{2}}+$ & $\begin{array}{l}-\quad 0.024 \text { Index }_{3} \\
+\end{array}$ & $\begin{array}{l}+0.032 \\
\text { Index }_{4}\end{array}$ \\
\hline & $(17.52)$ & $(3.169)^{*}$ & $(-0.071)$ & $(-0.932)$ & $(0.971)$ \\
\hline & + & + & $+0.064 \ln \operatorname{lex}_{8}$ & $+0.038 \operatorname{lndex} x_{11}$ & \\
\hline & $0.022^{\text {Index }} x_{5}$ & $0.083^{\text {Index }_{6}}$ & + & & \\
\hline & $(0.806)$ & $(3.059) *$ & $(2.182)^{*}$ & $(1.586$ & \\
\hline R-sq. & $=0.506$ & & & & \\
\hline F-test & $=19.058(0.000)$ & & \multicolumn{3}{|c|}{ Durbin-Watson $=1.650$} \\
\hline
\end{tabular}

Note: Value in parenthesis refers to t-value. Asterisk $(*)$ indicates that it is significant at 0.05 significant level.

The R-square for the constructed regression model is 0.506 , which indicates that, there is around $50.6 \%$ of the explanatory power of the independents used. In other words, there is an evident that the independent variables explained $50.6 \%$ of the 'Perceptions of the local community'. The other remaining $49.1 \%$ of the variables is explained by other rejected factors that explain for the low result of the R-square.

It also can be seen that the value for F-test is 19.058. Since the probability value for F-test (0.000) is lesser than alpha (0.05), therefore, there are enough statistical evidence to reject the

null hypothesis. This means that the model is significant at $95 \%$ confident level. Thus, this indicates that all the slope coefficients are statically significant simultaneously (the whole model is fit). To add, the Durbin-Watson value is 1.650. A value that is more than 1.5 shows that there is no autocorrelation problem arises in the disturbance or the error term.

\subsection{ANOVA T-test}

By referring to the probability value (p-value) of t-test for each variable (Table $\mathrm{X}$ ), it must lower than significant level of 5\%/alpha (0.05). By referring to the probability value (p-value) of t-test for each variable, it must lower than the significant level of $5 \%$ or alpha (0.05). From the computed regression model above, Index 1 , Index 4 , Index 5 , Index 6 , Index 8 and Index $_{11}$ shows a positive impact on perceptions of the local community. Whilst, Index 2 and $\mathrm{I}^{\text {Index }_{3}}$ show there is a negative impacts on factors influence the perceptions of the 
local community towards the wetlands management.

To summarize, only Index $_{1}$, Index $_{6}$ and Index $_{8}$, are significant at 5\% significant level. Thus, only these 3 indexes can be considered as influencing factors for the perception of the local community towards the implementation of wetlands management. The remaining indexes are not significant.

Table 4: SPSS Regression Output

\begin{tabular}{|c|c|c|c|c|c|}
\hline \multirow{2}{*}{ Model } & \multicolumn{2}{|c|}{ Unstandardized Coefficient } & \multicolumn{2}{|l|}{ Standardized } & \multirow{2}{*}{ Sig. } \\
\hline & $\mathrm{B}$ & Std. Error & Beta & & \\
\hline (Constant) & 2.174 & .124 & & 17.520 & .000 \\
\hline Index $_{1}$ & .118 & .037 & .335 & 3.169 & .002 \\
\hline Index $_{2}$ & -.004 & .055 & -.006 & -.071 & .944 \\
\hline $\operatorname{Index}_{3}$ & -.024 & .025 & -.074 & -.932 & .353 \\
\hline $\operatorname{Index}_{4}$ & .032 & .033 & .084 & .971 & .333 \\
\hline Index $_{5}$ & .022 & .027 & .055 & .806 & .421 \\
\hline $\operatorname{Index}_{6}$ & .083 & .027 & .262 & 3.059 & .003 \\
\hline Index $_{8}$ & .064 & .030 & .164 & 2.182 & .031 \\
\hline Index $_{11}$ & .038 & .024 & .099 & 1.586 & .115 \\
\hline
\end{tabular}




\section{Conclusion}

This research shows that the majority of local communities living adjacent to mangroves in the area of Kuching have a positive attitude towards conservation mangrove forest resources. Awareness campaigns and education of the younger generation should expand to the local communities to increase their participation in the conservation of mangrove forest resources.

Local communities living in the vicinity of wetlands recognize the contribution of wetlands for their livelihood. Some of them are dependent directly in front of the wetlands. Some have direct use values of wetlands forest harvesting, others may benefit indirectly through values that are not used. Wetlands forests are the habitat of sea and wildlife. Wetlands provide protection against sea water intrusions and implement flood mitigation and carbon sequestration. The commercial value of wetlands for charcoal production in the region showed that the forest should be managed and maintained. For example, one of Samariang community earns more than RM5, 000 a month by doing the charcoal business.

The Department of Forestry Sarawak has undertaken many conservation programs to increase the awareness of the local communities on the importance of conservation of the wetlands. Replanting programs to replace trees that have been harvested or destroyed have been carried for a number of years. besides, savage crocodile breeding is also of concern to local residents is causing difficulty for them to undertake their daily activities on wetlands and turned to look for income in the city is better for them. While conducting the survey, residents'

Samariang also hopes the government to tighten border area residents elsewhere is clearly to maintain wetlands acreage is decreasing. Samariang residents also hope the government can carry out activities such as gotong-royong, litter awareness campaign to encourage residents to reduce water pollution is increasing. Since Samariang is a village located in the city, but mangroves are very important especially for fishermen.

Most of the wetland local community does not contribute to ecotourism industry, thus the government can take opportunity to raise the awareness of the potential income that can be generated and the importance of sustaining the natural resources. The government can introduce activities that are suitable and effective management and conservation programs, particularly rehabilitation of mangrove ecology and allow local communities to participate.

\section{Acknowledgement}

Financial support from Fundamental Research Grant Scheme [FRGS/ E14099 F01 69 $1205 / 2016(06)]$ is gratefully acknowledged. All remaining flaws are the responsibilities of the authors.

\section{References}

Barbier, E. B., Acreman, M., \& Knowler, D. (1997). Economic valuation of wetlands: a guide for policy makers and planners. Gland: Ramsar Convention Bureau. 


\section{Ml Macrothink}

Journal of Public Administration and Governance

ISSN 2161-7104

2016, Vol. 6, No. 4

Chan, E., T.A. Bunsztynsky, N. Hantzsche, and Y.J. Litwin.(1993). The Use of Wetlands for Water Pollution Control. EPA-600/S2-82-086. EPA Municipal Environmental Research Lab., Cincinnati, $\mathrm{OH}$.

Chia, J. (2012, February 23). Kuching wetland national park to be important tourist draw. Borneo Post Online. Retrieved from http://www.theborneopost.com/2012/02/23/kuchingwetland-national-park-to-be-important-to urist-draw/

Fabrigar, L. R., Wegener, D. T., MacCallum, R. C., \& Strahan, E. J. (1999). Evaluating the use of exploratory factor analysis in psychological research. Psychological Methods, 4(3), 272-299.

Field, A. (2006). Reliability analysis. Retrieved from http://www.statisticshell.com/docs from http://www.statsoft.com/Textbook/Multiple-Regression

Gandhi, P. S. (2012). Calculating and Interpreting Reliability Estimates for Achievement Test in Graph Theory - (A modern branch of Mathematics). International Indexed \& Refferred Research Journal, 4(37), 36-37.

Gillespie, A. (2007). Protected areas and international environmental law. BRILL.

Grayson, J. E., Chapman, M. G., \& Underwood, A. J. (1999). The assessment of restoration of habitat in urban wetlands. Landscape and Urban planning, 43(4), 227-236.

Hair, J. F., Black, B., Babin, B., Anderson, R. E., \& Tatham, R. L. (2006). Multivariate Data Analysis. Upper Saddle, New Jersey: Pearson Prentice Hall.

Howitt, R (2001): Rethinking Resource Management: Justice, Sustainability and Indigenous Peoples: Routledge: UK

Kaiser, H. (1974). An index of factorial simplicity. Psychometrika, 39, 31-36.

Kline, P. (1999). The handbook of psychological testing (2nd ed.). London: Routledge

Laerd Statistics (n.d.). Cronbach's alpha ( $\alpha$ ) using SPSS statistics. Retrieved from https://statistics.laerd.com/spss-tutorials/cronbachs-alpha-using-spss-statistics.php

Laerd Statistics (n.d.). Multiple regression analysis using SPSS statistics. Retrieved from https://statistics.laerd.com/spss-tutorials/multiple-regression-using-spss-statistics.php

Meyers, L. S., Gamst, G., \& Guarino, A. J. (2006). Applied multivariate research: Design and interpretation. Thousand Oaks: Sage Publications.

Pomeroy, R. S., and M. B. Carlos. 1997. Community-based coastal resource management in the Philippines: a review and evaluation of programs and projects, 1984-1 994. Marine Policy 21(5):445-464.

Sarawak Forestry Corporation (2013). "World wetlands day 2013" at Kuching wetland national park. Retrieved from http://www.sarawakforestry.com/SFC/2013/02/16/world-wetlandsday- 


\section{Macrothink}

Journal of Public Administration and Governance ISSN 2161-7104 2016, Vol. 6, No. 4

Sharma, S. (1996). Applied Multivariate Techniques. New York: John Wiley and Sons Inc.

Shuib, A., Lee, S. Y., \& Edman, S. (2012). Attitude of local communities towards conservation of the mangrove ecosystem in Kuching, Sarawak. The Malaysian Forester. 75(1). 15-28.

StatSoft (n.d.). How to find relationship between variables, multiple regression. Retrieved from http://www.statsoft.com/Textbook/Multiple-Regression

Wetlands definition (n.d). What is a Wetland? Retrieved 2016, May 05 from https://www.epa.gov/wetlands/what-are-wetland-functions

Wetland International (n.d.). Ramsar sites in Malaysia. Retrieved from http://malaysia.wetlands.org/WHATWEDO/Allourprojects/tabid/513/ArticleType/ArticleVie w/ArticleId/128/Ramsar-sites-in-Malaysia.aspx

Wetlands International (n.d.). Wetlands of Malaysia. Retrieved from http://malaysia.wetlands.org/WhatareWetlands/WetlandsofMalaysia/tabid/506/Default.aspx

\section{Copyright Disclaimer}

Copyright for this article is retained by the author(s), with first publication rights granted to the journal.

This is an open-access article distributed under the terms and conditions of the Creative Commons Attribution license (http://creativecommons.org/licenses/by/3.0/). 